\title{
Early and long period follow-up results of low glycemic index diet for migraine prophylaxis
}

\author{
Migren profilaksisinde düşük glisemik indeks diyetin erken ve geç dönem izlem sonuçları
}

\author{
Gökhan EVCiLi,', Uygar UTKU,' Muhammed Nur ÖĞÜN,' Gökhan ÖZDEMiR²
}

\begin{abstract}
Summary
Objectives: The role of dietary restriction in the management of patients with migraine is still a controversial topic in the headache field. The aim of this study was to evaluate the efficacy of dietary restriction on migraine attacks.

Methods: Patients diagnosed with migraine without aura according to the International Classification of Headaches were enrolled. Our study included 350 migraine patients evaluated at the neurology headache outpatient clinic. They were randomly divided into two groups: diet group as the study group and medication group as the control group. We told migraine patients to make lifestyle changes, especially those with low glycemic index in the diet group. On the other hand, propranolol, amitriptyline, flunarizine, and topiramate were used for the prophylaxis in the medication group. The frequency and severity of attacks [using the visual analog scale (VAS)] were recorded before starting dietary restriction and 1 and 3 months after the dietary restriction. Results: There were 350 participants in this study. After 3 months, a total of 147 patients (male/female: 17/130, mean age: $34.7 \pm 5.9$ ) were evaluated in the diet group. The control group consisted of 147 age- and sex-matched, randomly selected patients with migraine without aura. In the first month after dietary restriction, monthly attack frequency significantly decreased in both groups but not the VAS score. The mean scores of VAS significantly decreased later in the diet group compared with those in the medication group (after 3 months).
\end{abstract}

Conclusion: The results of the study revealed that low glycemic index diet intake can be an effective and reliable method to reduce migraine attacks.

Keywords: Dietary restriction; low glycemic index; migraine.

\begin{abstract}
Özet
Amaç: Migren hastalarının tedavisinde diyetin rolü halen baş ağrısı alanında tartışmalı bir konudur. Bu çalışmanın amacı, diyet kısıtlamasının migren atakları üzerindeki etkinliğini değerlendirmektir.

Gereç ve Yöntem: Baş ağrısı uluslararası sınıflandırmasına göre aurasız migren tanısı alan hastalar kayda alındı. Çalışmamız nöroloji baş ağrısı polikliniğinde değerlendirilen 350 migren hastasını içermektedir. Hastalar randomize olarak iki gruba ayrıldı; diyet grubu çalışma grubu, ilaç grubu kontrol grubu olarak alındı. Diyet grubundaki migren hastalarına yaşam tarzı değişikliği özellikle de düşük glisemik indeksli diyet uygulamalarını söyledik. İlaç grubunda profilaktik tedavi için propranolol, amitriptilin, flunarizin ve topiramat kullanıldı. Diyet kısıtlamasına başlamadan önce ve diyet kısıtlamasından bir ay ve üç ay sonra migren atak sıklığı ve şiddeti görsel analog skala kullanılarak (VAS) kaydedildi.

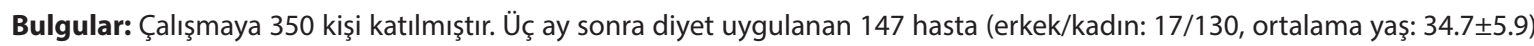
değerlendirildi. Kontrol grubu (ilaç) 147 yaş ve cinsiyet uyumlu, rastgele seçilmiş aurasız migren hastalarından oluşmaktadır. Diyet kıııllamasından sonraki ilk ayda, aylık atak sıklığı her iki grupta anlamlı olarak azalırken VAS'ı azaltmadı. VAS ortalama değerleri, diyet grubunda ilaç grubuna göre daha sonra anlamlı olarak azalmıştır (üç ay sonra).

Sonuç: Çalışmanın sonuçları düşük glisemik indeksli diyet alımının migren ataklarını azaltmak için etkili ve güvenilir bir yöntem olabileceğini ortaya koymaktadır.
\end{abstract}

Anahtar sözcükler: Diyet kısıtlaması; düşük glisemik indeks; migren.

'Department of Neurology, Kocaeli Derince Training and Research Hospital, Kocaeli, Turkey

${ }^{2}$ Department of Neurology, Atatürk University, Erzurum, Turkey

Submitted (Başvuru tarihi) 23.05.2017 Accepted after revision (Düzeltme sonrası kabul tarihi) 29.11.2017 Available online date (Online yayımlanma tarihi) 29.01.2018

Correspondence: Dr. Uygar Utku. Kocaeli Derince Eğitim ve Araştırma Hastanesi Nöroloji Kliniği, 41900 Kocaeli, Turkey.

Phone: +90 - 505 - 5725932 e-mail: uygarutku@yahoo.com

๑) 2018 Turkish Society of Algology 


\section{Introduction}

The relationship between migraine headache and factors such as environmental factors, stress, chronic diseases, and nutritional and sleep status has been known although their mechanisms are still not clear. The roles of nutritional factors that trigger migraine have become much more questionable with the increase in the rate of migraine occurrence. Effects of nutrition play an important role as pain triggers in migraine patients; however, each patient may not have the same sensitivity to these triggers. Moreover, it is known that caffeine, chocolate, fermented foods (such as cheese and pickle), monosodium glutamate, and alcohol may trigger migraine. ${ }^{[1-3]}$

The aim of this study was to determine the associations of low dietary glycemic index with migraine headache.

\section{Material and Methods}

Our study included 350 patients with migraine without aura; they were evaluated at a headache outpatient clinic. Patients under the age of 18 years were not included in the study. Migraine without aura is diagnosed according to International Headache Classification. ${ }^{[4]}$ The patients who were included in the study were previously not under any kind of treatment such as medication and/or interventional therapy for headache. They were randomly divided into two groups: diet group as the study group and medication group as the control group.

We told migraine patients to make lifestyle changes and dietary restriction, especially those with low glycemic index in the diet group. A low glycemic index diet form was prepared by a dietician. Our dietician has been given a wide list of foods that should be taken care of, especially consumed (low glycemic index) and not consumed (high glycemic index). Patients act according to this list, which is very understandable, and continue their diet by communicating with our dietician if necessary. As an example of a list of foods that we do not want them to consume and have high glycemic index included all kinds of bread, bagels, toast, dry and wet pastries, pastries, rice, pasta, potatoes, corn, sugar, chocolate, sweeties, jams, honey, molasses, sweeteners, ready-made fruit juices, sugary carbonated drinks, watermelon, melon, fries, milk powder and cream. We recom- mended the frequency of feeding as three main and three intervals. Diabetic patients were excluded from the study.

On the other hand, propranolol (40-80 mg/day), amitriptyline ( $25-75 \mathrm{mg} /$ day), flunarizine (10 mg/day), and topiramate (50-100 mg/day) are used for prophylaxis in the medication group during the study. Also, simple analgesics, non-steroid anti-inflammatory agents, ergot alkaloids, and triptans were used to treat acute migraine attacks for both groups. The frequency and severity of the attacks [using the visual analog scale (VAS)] were recorded before starting dietary restriction and 1 and 3 months after the dietary restriction. Compliance of patients to the dietary protocol during the study period was especially controlled at routine outpatient visits. It was determined by face-to-face interview. Incompatible patients such as low sociocultural patients were excluded from the study.

\section{Visual Analog Scale}

Daytime and nighttime pain were evaluated using VAS, a $10-\mathrm{cm}$ horizontal line, where the end points 0 and 10 indicated no pain and worst possible pain, respectively. VAS was also used for assessing the pain felt during the procedure.

\section{Statistical Analysis}

Data analysis was performed using the Statistical Packages for the Social Sciences (SPSS Inc; Chicago, IL, USA) for Windows 15.0 package. Descriptive statistics were shown as a mean \pm standard deviation for continuous variables and as case number and percentage for nominal variables. Whether the distribution of continuous variables was near normal was investigated using the Kolmogorov-Smirnov test. In comparison with the pre-treatment, whether statistically significant changes occurred in the second and fourth months after treatment were compared using the Wilcoxon signed-rank test. The differences between the groups were examined using the independent samples t-test and Mann-Whitney $U$ test. $P$ values of $<0.05$ were accepted to be statistically significant.

\section{Results}

There were 350 participants in this study. After 3 months, a total of 147 patients (male/female: 17/130, mean age: $34.7 \pm 5.9)$ were evaluated in the diet 
Table 1. The evaluation of changes in clinical measurements before and after treatment between the two groups

\begin{tabular}{lccl}
\hline & $\begin{array}{c}\text { Diet Group } \\
(\mathbf{n}=\mathbf{1 4 7})\end{array}$ & $\begin{array}{c}\text { Medication Group } \\
(\mathbf{n}=\mathbf{1 4 7})\end{array}$ & \\
\hline VAS (mean) & & & \\
Beginning & 8.46 & 8.47 & $>0.05$ \\
After 30 days & 8.46 & 1.25 & $<0.05$ \\
After 90 days & 1.23 & 1.18 & $>0.05$ \\
Number of attacks & & & \\
(Per month)(mean) & & & \\
Beginning & 7.49 & 7.53 & $>0.05$ \\
After 30 days & 3.68 & 2.91 & $>0.05$ \\
After 90 days & 3.42 & 2.74 & $>0.05$ \\
\hline
\end{tabular}

*VAS: Visual analog scale

group. The control group (medication) consisted of 147 age- and sex-matched, randomly selected patients with migraine without aura. There was no past history of any major illnesses, and family histories were unremarkable in both group. Propranolol $(n=80 ; 54.42 \%)$, amitriptyline $(n=50 ; 34.01 \%)$, topiramate $(n=15 ; 10.20 \%)$, and flunarizine $(n=2 ; 1.36 \%)$ were used for prophylaxis in the control group during the study. In the first month after diet restriction, attack frequency significantly decreased in both groups but not VAS score $(p<0.05)$. The mean scores of VAS significantly decreased after 3 months in the diet group compared with those in the medication group after 3 months $(p<0.05)$ (Table 1$)$.

\section{Discussion}

Our study has provided support for drug treatment rather than finding an alternative to the original drug treatment in migraine headache. It is known that consumed nutrients directly or indirectly affect the brain, and diet restriction is used in the treatment of some diseases such as epilepsy, but low glycemic index treatment is a newly developed dietary therapeutic option for epilepsy that is less restrictive than the ketogenic diet. ${ }^{[5]}$ We would like to investigate the effects of hunger and diet on migraine. We compared applied drug treatment in the diet group and the control group, and we found that diet restriction, especially low glycemic index diet, is as effective as drug treatment. Both VAS scores showed a significant decrease in the frequency of headache attacks in the diet and control (medication) groups.
However, the event was time-varying. The effects of dietary restriction were not yet observed at the next month's check-up in the diet group. On the other hand, there was a statistically significant improvement in the drug group.

The glycemic index is a measure of the blood glucose-raising potential of carbohydrates. Carbohydrate-containing foods can be classified as high $(\geq 70)$, moderate (56-69), or low glycemic index $(\leq 55)$ relative to pure glucose. When the amount of fiber in foods increases, glycemic index decreases. This group of foods is slow to digest, and they stay in the stomach and intestines for a long time and slowly pass into the blood as glucose, so they slowly raise blood glucose level or keep at the same level. ${ }^{[6]}$ This can be the underlying mechanism. Hypertension, diabetes, high cholesterol, and obesity have been reported to be common in patients with chronic migraine. Evans et al. reported that a lower glycemic diet may lead to important reductions in blood pressure. Parameters such as body weight, body mass index, fat mass, total cholesterol, LDL-cholesterol, HDL-cholesterol, triglycerides, and diastolic and systolic blood pressure significantly decreased with low glycemic index diet. ${ }^{[7]}$ Increased blood pressure may cause headache. Blood lipids, glucose, insulin, and insulin resistance (homeostasis model assessment) were not determined in both groups. This was a limitation of our study.

The relationship between migraine and obesity has begun to attract more attention in the last years. In a recent study, patients with various types of headache were evaluated, and these patients were divided into five groups according to body mass index (weak, normal, overweight, obese, and morbid obese). The highest prevalence of migraine was found in morbid obese women. ${ }^{[8]}$ The underlying mechanism through which overweight causes headache is that central obesity increases abdominal pressure, which decreases cerebral venous return. ${ }^{[9]}$ Perhaps after low glycemic index diet, body mass index of these patients decreased. We do not know this. This was a limitation of our study.

\section{Conclusions}

The results of the study reveal that low glycemic index diet intake can be an effective and reliable method to reduce migraine attacks. 
Conflict-of-interest issues regarding the authorship or article: None declared.

\section{Peer-rewiew: Externally peer-reviewed.}

\section{References}

1. Martin VT, Vij B. Diet and Headache: Part 1. Headache 2016;56(9):1543-52. [CrossRef]

2. Martin VT, Vij B. Diet and Headache: Part 2. Headache 2016;56(9):1553-62. [CrossRef]

3. Orr SL. Diet and nutraceutical interventions for headache management: $A$ review of the evidence. Cephalalgia 2016;36(12):1112-33. [CrossRef]

4. Headache Classification Subcommittee of the International Headache Society. The International Classification of Headache Disorders: 2 nd edition. Cephalalgia 2004;24 Suppl 1:9-160.

5. Kim SH, Kang HC, Lee EJ, Lee JS, Kim HD. Low glycemic index treatment in patients with drug-resistant epilepsy. Brain Dev 2017;39(8):687-92. [CrossRef]

6. Monro JA, Shaw M. Glycemic impact, glycemic glucose equivalents, glycemic index, and glycemic load: definitions, distinctions, and implications. Am J Clin Nutr 2008;87(1):237S-43S. [CrossRef]

7. Evans $C E$, Greenwood DC, Threapleton DE, Gale CP, Cleghorn CL, Burley VJ. Glycemic index, glycemic load, and blood pressure: a systematic review and metaanalysis of randomized controlled trials. Am J Clin Nutr 2017;105(5):1176-90. [CrossRef]

8. Özturan A, Şanlıer N, Coşkun Ö. The relationship between migraine and nutrition. Turk J Neurol 2016;22(2):44-50.

9. Schlosser RJ, Woodworth BA, Wilensky EM, Grady MS, Bolger WE. Spontaneous cerebrospinal fluid leaks: a variant of benign intracranial hypertension. Ann Otol Rhinol Laryngol 2006;115(7):495-500. [CrossRef] 